\title{
Overheating of Device
}

National Cancer Institute

\section{Source}

National Cancer Institute. Overheating of Device. NCI Thesaurus. Code C62883.

Problem associated with the device producing high temperatures, such that its operation is compromised or harm is caused (e.g. overheating that produces melting of components or automatic shutdown). 